\title{
Some Physical and Chemical Properties of Fruitbodies of Cordyceps militaris Collected in Turkey
}

\author{
Özge SÜFER ${ }^{1 *}$, Fuat BOZOK ${ }^{2}$, Hatıra TAŞKIN ${ }^{3} \oplus$, Saadet BÜYÜKALACA ${ }^{3} \odot$ \\ ${ }^{1}$ Osmaniye Korkut Ata University, Faculty of Engineering, Department of Food Engineering, Osmaniye, \\ TURKEY \\ ${ }^{2}$ Osmaniye Korkut Ata University, Faculty of Arts and Science, Department of Biology, Osmaniye, \\ TURKEY \\ ${ }^{3}$ Çukurova University, Faculty of Agriculture, Department of Horticulture, Adana, TURKEY \\ "Corresponding author: ozgesufer@osmaniye.edu.tr
}

Received Date: 10.12 .2018

Accepted Date: 01.04.2019

Abstract

Aim of study: Turkish Cordyceps militaris was collected in order to determine its certain quality characteristics such as color, texture, total phenolics level and antioxidant activity.

Material and method: Samples (not cultivated, wild) which were harvested from a field of Istanbul in 2018 were analyzed by using Eurx genematrix universal isolation kit for determining total genomic DNA. Color and textural properties of $C$. militaris body were measured by a colorimeter (according to Munsell system) and texture analyzer (applying texture profile analysis, TPA) respectively. The methanolic extract of C. militaris was subjected to total phenolic determination (by Folin Ciocalteu method) and antioxidant activity (by DPPH method) tests.

Main results: $\mathrm{L}^{*}, \mathrm{a}^{*}, \mathrm{~b}^{*}, \mathrm{C}^{*}, \mathrm{H}^{\circ}$ (color) values were recorded as 34.96, 18.84, 21.22, 28.41 and 48.57 respectively. Hardness of samples was $26.25 \mathrm{~N}$. Total phenolic amounts and DPPH radical scavenging activity of specimens were found as $2316.22 \mathrm{mg}$ gallic acid equivalent (GAE)/L extract and $3.98 \mathrm{mg}$ trolox equivalent (TE)/L extract.

Highlights: The recommendation of this preliminary study is that $C$. militaris may be useful in various food formulations as an ingredient because of its high bioactive molecule and antioxidant potential.

Keywords: Biological Activity, Cordycipitaceae, Medicinal Macrofungi

\section{Türkiye'den Toplanan Cordyceps militaris'in Bazı Fiziksel ve Kimyasal Özellikleri}

Öz

Çalışmanin amact: Türk Cordyceps militaris'i, renk, doku, toplam fenolik düzeyi ve antioksidan aktivite gibi bazı kalite özelliklerinin belirlenmesi amacıyla toplanmıştır.

Materyal ve metod: 2018 y1lında İstanbul'daki bir araziden toplanan mantar örnekleri (kültür ortamında yetişmemiş, yabani) Eurx genematrix universal isolation kit kullanılarak toplam genomik DNA'nın belirlenmesi için analiz edilmiştir. C. militaris gövdesinin renk ve dokusal özellikleri sırasıyla bir renk ölçer (Munsell sistemine göre) ve doku analizörü (doku profili analizi, TPA uygulanarak) vasitasıyla tayin edilmiştir. C. militaris'in metanol içerisinde hazırlanmış özütü, toplam fenolik tayinine (Folin Ciocalteu yöntemi) ve antioksidan aktivite testine (DPPH yöntemi) tabi tutulmuştur.

Sonuçlar: $\mathrm{L}^{*}, \mathrm{a}^{*}, \mathrm{~b}^{*}, \mathrm{C}^{*}, \mathrm{H}^{\circ}$ (renk) değerleri sirasıly $34.96,18.84,21.22$, 28.41 ve 48.57 olarak kaydedilmiştir. Örneklerin sertliği 26.25 N'dir. Numunelerin toplam fenolik miktarı ve DPPH radikali süpürme aktivitesi $2316.22 \mathrm{mg}$ gallik asit eşdeğeri (GAE)/L özüt ve $3.98 \mathrm{mg}$ troloks eşdeğeri (TE)/L özüt olarak bulunmuştur.

Önemli vurgular: $\mathrm{Bu}$ ön çalışmanın önerisi, C. militaris'in yüksek biyoaktif molekül ve antioksidan potansiyelinden dolayı, çeşitli gıda formülasyonlarında bir besin öğesi olmasının yararlı olabileceğidir.

Anahtar Kelimeler: Biyolojik Aktivite, Cordycipitaceae, Tibbi Makromantar 


\section{Introduction}

Cordyceps militaris which belongs to the family Cordycipitaceae (Ascomycota) is an entomopathogenic fungal species that lives on pupa and larva of lepidopteran insects as parasitic (Kirk, Cannon, David \& Stalpers, 2008; Masuda, Urabe, Sakurai \& Sakakibara, 2006). Cordyceps species are known as medicinal macrofungi in Far East Countries such as China and Japan. Also, in East Asia, cultivated $C$. militaris is accepted as a folk tonic food (Wu et al. 2014).

An increment of reactive oxygen species in healthy cells may cause several pathological effects like DNA damages, diabetes, cancer and so on. In order to eliminate these health risks, discovering and developing new natural antioxidants will be useful for living organisms (Liu, Jia, Kan \& Jin, 2013). The species belonging to Cordyceps genus includes various bioactive compounds (cordycepin, ophiocordin and some polysaccharides etc.) that have antioxidant, antimicrobial, anti-inflammatory, antitumor activities (Yoo et al 2004; Won \& Park, 2005; Zhan, Dong \& Yao, 2006; Reis et al., 2013). Especially cordycepin was extensively investigated because of its inhibiting action on tumors. The mechanism of cordycepin on tumors based on the inhibition of migration and invasion of cancer cells, blockage of metastasis and disruption between cancer and mesenchymal stromal cells (Jin et al., 2018).

On the other hand, the amino acid contents of cultivated fruit bodies of $C$. militaris were also described by Zhan et al. (2006) and the major ones were isoleucine, glutamic acid, arginine and aspartic acid. Hypolipidemic, antitumor, antioxidant, antibacterial and antiinflammatory effects of some Cordyceps species were also previously assessed by many researchers (Yang et al., 2000; Yoo et al., 2004; Won and Park, 2005; Leung, Zhao, Ho \& Wu, 2009; Huang, Siu, Wang, Cheung \& Wu, 2013; Reis et al., 2013; Chen et al., 2014; Jing et al., 2014; Wang et al., 2015).

Cordyceps militaris was first reported from Turkey very recently, from Istanbul province (Akata, Kabaktepe \& Akgül, 2016). This drawing scientific attention species however has not been studied in Turkey in respect of its biological activity and nutritional properties. In this paper we report certain physical and chemical characteristics of collected from nature Turkish $C$. militaris.

\section{Materials and Methods}

Macrofungi sample, DNA isolation, PCR and sequencing

Macrofungi samples (voucher no FBozok00139) were collected from Istanbul province of Turkey on 15 April 2018 (Figure 1) and deposited at Fungarium of Osmaniye Korkut Ata University. Total genomic DNA was isolated from fresh samples by using Eurx genematrix universal isolation kit with slight modifications (concentrations and amounts of RNase $(10 \mu \mathrm{l}, 10 \mathrm{mg} / \mathrm{ml})$ and Proteinase K (10 $\mu \mathrm{l}, 20 \mathrm{mg} / \mathrm{ml})$ were increased). ITS gene region was amplified with ITS1F and ITS4 primers (White, Bruns, Lee \& Taylor, 1990). PCR conditions were as follows: $94^{\circ} \mathrm{C}$ for 5 min, followed by 30 cycles for $30 \mathrm{~s}$ at $94^{\circ} \mathrm{C}$, for $45 \mathrm{~s}$ at $53^{\circ} \mathrm{C}$, for $60 \mathrm{~s} 72^{\circ} \mathrm{C}$ and final extension for $5 \mathrm{~min}$ at $72^{\circ} \mathrm{C}$. DNA sequence analysis was made by BigDye Terminator (version 3.1) Sequencing Kit using ITS1FITS4 primers again and raw sequence was edited by Sequencer version 5.4.5 (Gene codes, Ann Arbor, MI, USA) and aligned by Bioedit programme. This sequence was deposited in GenBank as accession MK131341. When compared to the sequences in the public GenBank database, the sequence obtained in the present study shows similarity 100\% with JX488477 (China), HQ591382 (Taiwan), AB070375 (Japan), JX488481 (South Korea), JN121122 (Germany), JX488479 (China) and JN488478 (USA).

\section{Moisture Determination}

Moisture content of fresh samples was measured according to the air oven method of AACC (1995) numbered as 44-15A.

\section{Color Analysis}

Colorimetric measurements of specimens were identified in triplicate using a portable device (Konika Minolta, Chroma meter, CR400, Japan). L* (brightness), a* (rednessgreeness) and $\mathrm{b}^{*}$ (yellowness-blueness) were measured. Chroma $\left(\mathrm{C}^{*}\right)$ and hue angle $\left(\mathrm{H}^{\circ}\right)$ values were also calculated from equation 1 and 2 respectively. 


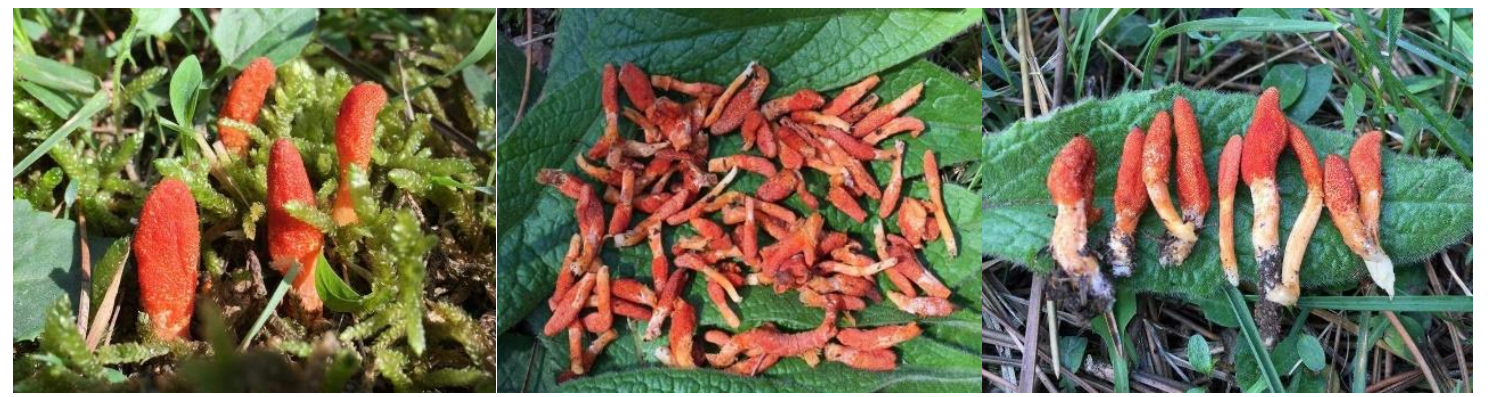

Figure 1. Cordyceps militaris (photographed by Mr. Naim Güleç)

$$
\mathrm{C}^{*}=\sqrt{\left(a^{*}\right)^{2}+\left(b^{*}\right)^{2}}
$$

Equation 1. The quality of color (chroma) equation

$$
\mathrm{H}^{\circ}=\arctan \left(\frac{b^{*}}{a^{*}}\right)
$$

Equation 2. The mathematical expression of hue angle

\section{Texture Profile Analysis (TPA)}

Texture analysis of $\mathrm{C}$. militaris was performed by a texture analyzer (Brookfield, CT3, load cell:4500 g, USA). The samples were compressed $1 \mathrm{~mm}$ and test and post speed were $1 \mathrm{~mm} / \mathrm{s}$ and $2 \mathrm{~mm} / \mathrm{s}$ respectively. Trigger load was $3 \mathrm{~N}$ and a cylindrical probe which had $2 \mathrm{~mm}$ diameter and $20 \mathrm{~mm}$ length was used. Five measurements were taken. Tested textural parameters were hardness, springiness, adhesiveness, gumminess and chewiness.

\section{Extraction of Bioactive Compounds}

Before total phenolics and antioxidant activity analysis, bioactive molecules were extracted from $C$. militaris by using the modified method of Bennett et al. (2011). 1 gram of chopped sample was diluted with 10 $\mathrm{ml} \mathrm{100 \%} \mathrm{methanol.} \mathrm{After} \mathrm{blending} \mathrm{for} 15 \mathrm{~s}$ (Wisd VM-10 Vortex mixer, Italy), mixture was put in an ultrasonic water bath (Selecta$\mathrm{HD} 5$ liters) at $25^{\circ} \mathrm{C}$ for $20 \mathrm{~min}$ and then it was centrifuged (Hettich Zentrifugen, Rotina 380, Germany) at $3500 \mathrm{rpm}$ during $15 \mathrm{~min}$. The supernatant was collected and used for experiments immediately.

\section{Total Phenolic Content}

Total phenolic determination was conducted according to the method of Li et al. (2015) with some modifications. $0.5 \mathrm{ml}$ extract was reacted with $0.5 \mathrm{ml}$ FolinCiocalteu reagent. After that, $3 \mathrm{ml} 10 \%$ $\mathrm{Na}_{2} \mathrm{CO}_{3}$ solution was added and the mixture was left for incubation in dark for 30 minutes. The absorbance was read at $760 \mathrm{~nm}$ by a UVvis spectrophotometer (UV-1800, Shimadzu, Japan) and result was given as mg gallic acid equivalents (GAE). 100\% methanol was accepted as blank and analysis was carried out triplicate.

\section{Antioxidant Activity (DPPH method)}

$0.1 \mathrm{ml}$ extract was added to $2 \mathrm{ml} 0.063 \mathrm{M}$ 2,2-Diphenyl-1-picrylhydrazyl (DPPH) solution. The absorbance of mixture was read at $517 \mathrm{~nm}$ by a UV-vis spectrophotometer (UV-1800, Shimadzu, Japan) after $30 \mathrm{~min}$ waiting in dark place (Aghraz et al 2018). The result was expressed as $\mathrm{mg}$ 6-Hydroxy2,5,7,8-tetramethylchromane-2-carboxylic acid (trolox) equivalents (TE). The test was performed in triplicate.

\section{Statistical Analysis}

The data of bioactive compounds was analyzed using Student's t-test $(p<0.05)$ by using SPSS version 18 (IBM, USA) which was a common statistical software. Means and standard deviations were also evaluated by same computer programme.

\section{Results and Discussion}

The calculated moisture level of $C$. militaris was $79.49 \% \pm 1.07 \quad(p<0.05) . \quad \mathrm{Li}$, Yang, Yang, Wang \& Chen (2019) claimed that $C$. militaris had high moisture content and easily perishable. Hence, drying may retard 
microbial deterioration and help to preserve quality. Furthermore, the drying effect on the antioxidant activity of polysaccharide from $C$. militaris was studied by Chen, Liu, Yang, Zhou \& Yang (2016) and freeze drying was reported as suitable method among hot air and spray drying.

Color is one of the most important parameters which have the ability of influencing the consumers' choice in a food product. Table 1 presents the color properties of macrofungi and $\mathrm{L}^{*}, \mathrm{a}^{*}$ and $\mathrm{b}^{*}$ values were recorded as $34.96 \pm 0.86,18.84 \pm 2.69$ and $21.22 \pm 0.97$ respectively $(p<0.05)$. When $\mathrm{a}^{*}$ value increase, the redness of sample also enhances. Characteristic orange-red color (high a*) of $C$. militaris may be originated from bioactive compounds like lycopene and cyanidin-3-glucoside and significant correlations between red pigments and redness of $C$. militaris have been reported by $\mathrm{Li}$ et al (2019). On the other hand, chroma defines the purity of color, however hue angle expresses strict distinction between colors. Chroma was $28.41 \pm 2.40$ and hue angle was $48.57 \pm 3.17$ in this study.

Great textural properties in edible mushrooms can directly affect the preferences of individuals as well as color attributes. The chewing motion is simulated by TPA (Ma, Zhang \& Zhao, 2019) and the results of TPA of $C$. militaris are shown in Table 1. Hardness $(37.10 \mathrm{~N})$ of Boletus edulis stems was reported higher than $C$. militaris (Jaworska \& Bernaś, 2010). Also, Agaricus bisphorus had a harder texture $(55.68 \mathrm{~N})$ than both $B$. edulis and C. militaris (Jaworska, Bernaś, Biernacka \& Maciejaszek, 2010).

Folin-Ciocalteu technique enables to detect total polyphenol levels and total phenolics determination can be accepted as a measure of antioxidant activity. DPPH procedure is a well-known method for rapid testing the natural antioxidant capacities $(\mathrm{Xu}$ et al., 2012). Total phenolics and DPPH radical scavenging activity of $C$. militaris were found as $2316.22 \pm 45.23 \mathrm{mg}$ GAE/L extract (or $23.16 \mathrm{mg}$ GAE/g sample) and $3.98 \pm 0.24 \mathrm{mg}$ TE$/ \mathrm{L}$ extract (or $0.03 \mathrm{mg} \mathrm{TE} / \mathrm{g}$ sample) respectively (on wet basis) $(p<0.05)$. These results indicate that wild $C$. militaris procured from Istanbul has a good potential of antioxidant activity. The stronger capability of
C. militaris in reducing oxidant molecules is coming from higher concentration of polysaccharides (Nie, Cui, Xie, Phillips \& Phillips, 2013).

While regarding previous studies, $\mathrm{Yu}$, Wang, Shiow \& Duh (2006) assessed the total phenolic amount and antioxidant capacity of water extracts of $C$. militaris and $C$. sinensis fruitbodies. They found the polyphenolic contents of both species was $60.2 \mu \mathrm{g} \mathrm{GAE} / \mathrm{mL}$ and $31.8 \mu \mathrm{g}$ GAE $/ \mathrm{mL}$ respectively and the antioxidant activity increased depending on the dose increased. These findings may demonstrate that methanol which has a high polarity might be more efficient than water for extraction of polyphenols from Corydceps species taking into account the results reported in this paper. Similarities were declared by Wang et al. (2015) in natural and cultured $C$. sinensis and their polyphenol contents in water extracts were given as 17.07 $\mathrm{mg} \mathrm{GAE} / \mathrm{g}$ for cultured and (averagely) 12.08 $\mathrm{mg}$ GAE/g for naturals. Also, C. militaris had higher polyphenol content than some wild and commercial mushrooms such as A. bisphorus, A. silvaticus, A. silvicola, Boletus edulis, Calocybe gambosa, Cantharellus cibarius, Craterellus cornucopioides and Marasmius oreades (Barros, Cruz, Baptista, Estevinho \& Ferreira, 2008).

Won and Park (2005) investigated the pharmacological activities of $70 \%$ ethanolic extract of $C$. militaris (cultured mycelia) and found that the IC50 value (which meant that the required concentration of scavenging the $50 \%$ of DPPH solution) of the extract was $0.026 \mathrm{~g} / \mathrm{mL}$ and this result implied the weak antioxidant activity of related macrofungi when compared with vitamin $\mathrm{C}$ as a synthetic antioxidant. Furthermore, Yu et al. (2007) studied in vitro antioxidant activity by hydroxyl radical system of the water-soluble and three different fractions polysaccharide (P50-1, P70-1 and P70-2) from fruiting bodies of cultivated $C$. militaris and found that P701 possessed hydroxyl radical-scavenging activity with an IC50 value of $0.548 \mathrm{mg} / \mathrm{ml}$. The comparisons of these researches with our data are difficult because of differences in testing methods. 


\section{Conclusion}

In this study, color, textural and antioxidant properties and polyphenolic compounds of $C$. militaris from Turkey were investigated. Results of this preliminary study showed that Turkish $C$. militaris has light orange color and its tissue was softer than other mushroom species. High bioactive and antioxidant potentials were discovered in methanolic extract. Hence, C. militaris may take part in food formulations as a useful nutrient. Also, its physical properties make it suitable for direct consumption. Future works which will focus on polysaccharides and specific phenolic constitutents of $C$. militaris naturally grow from Turkey must be conducted.

\section{Acknowledgement}

The authors are deeply grateful to $\mathrm{Mr}$. Naim Güleç for his helps in field studies.

\section{References}

AACC-The American Association of Cereal Chemists. (1995). Method 44-15A. Approved methods of the AACC ( $9^{\text {th }}$ ed). St. Paul, MN: American Association of Cereal Chemists.

Akata, I., Kabaktepe, Ş., \& Akgül, H. (2016). Cordyceps militaris, The first record from family Cordycipitaceae in Turkey. Kastamonu University Journal of Forestry Faculty, 16(1), 280-284.

Bennett, L. E., Jegasothy, H., Konczak, I., Frank, D., Sudharmarajan, S. \& Clingeleffer, P. R. (2011). Total polyphenolics and anti-oxidant properties of selected dried fruits and relationships to drying conditions. Journal of Functional Foods, 3(2), 115-124.

Barros, L., Cruz, T., Baptista, P., Estevinho, L. M., \& Ferreira, I. C. F. R. (2008). Wild and commercial mushrooms as source of nutrients and nutraceuticals. Food and Chemical Toxicology, 46(8), 2742-2747.

Chen, R., Jin, C., Li, H., Liu, Z., Lu, J., Li, S. \& Yang, S. (2014). Ultrahigh pressure extraction of polysaccharides from Cordyceps militaris and evaluation of antioxidant activity. Separation and Purification Technology, 134, 90-99.

Chen, W., Liu, G., Yang, H., Zhou, H. \& Yang, H. (2016). Effects of processing treatments on the antioxidant properties of polysaccharide from Cordyceps militaris. International Journal of Food Engineering, 13(1).

Huang, Q. L., Siu, K. C., Wang, W. Q., Cheung, Y. C. \& Wu, J. Y. (2013). Fractionation, characterization and antioxidant activity of exopolysaccharides from fermentation broth of a Cordyceps sinensis fungus. Process Biochemistry, 48(2), 380-386.

Jaworska, G. \& Bernaś, E. (2010). Effects of pretreatment, freezing and frozen storage on the texture of Boletus edulis (Bull: Fr.) mushrooms. International Journal of Refrigeration, 33, 877-885.

Jaworska, G., Bernaś, E., Biernacka, A. \& Maciejaszek, I. (2010). Comparison of the texture of fresh and preserved Agaricus bisporus and Boletus edulis mushrooms. International Journal of Food Science \& Technology, 45, 1659-1665.

Jin, Y., Meng, X., Qiu, Z., Su, Y., Yu, P. \& Qu, P. (2018). Anti-tumor and anti-metastatic roles of cordycepin, one bioactive compound of Cordyceps militaris. Saudi Journal of Biological Sciences, 25(5), 991-995.

Jing, Y., Cui, X., Chen, Z., Huang, L., Song, L., Liu, T., Lv, W. \& Yu, R. (2014). Elucidation and biological activities of a new polysaccharide from cultured Cordyceps militaris, Carbohydrate Polymers, 102, 288296.

Kirk, P. M., Cannon, P. F., David, J. C. \& Stalpers, J. A. (2008). Ainsworth \& Brisby's dictionary of the fungi (10th ed.). Wallingford, U.K.: CAB International.

Leung, P. H., Zhao, S., Ho, K. P. \& Wu, J. Y (2009). Chemical properties and antioxidant activity of exopolysaccharides from mycelial culture of Cordyceps sinensis fungus Cs-HK1. Food Chemistry, 114, 1251-1256.

Li, X., Wasila, H., Liu, L., Yuan, T., Gao, Z., Zhao, B. \& Ahmad, I. (2015). Physicochemical characteristics, polyphenol compositions and antioxidant potential of pomegranate juices from 10 Chinese cultivars and the environmental factors analysis. Food Chemistry, 175, 575-584.

Li, Y., Yang, H., Yang, H., Wang, J. \& Chen, H. (2019). Assessment of drying methods on the physiochemical property and antioxidant activity of Cordyceps militaris. Journal of Food Measurement and Characterization, 13(1), 513-520.

Liu, J., Jia, L., Kan, J. \& Jin, C-H. (2013). In vitro and in vivo antioxidant activity of ethanolic extract of white button mushroom (Agaricus bisporus). Food and Chemical Toxicology, 51(1), 310-316.

Ma, L., Zhang, M. \& Zhao, S. (2019). Effect of radio frequency heating on microbial load, flavor, color and texture profiles of Cordyceps militaris. Journal of the Science of the Food and Agriculture, 99(1), 136-142. 
Masuda, M., Urabe, E., Sakurai, A. \& Sakakibara, M. (2006). Production of cordycepin by surface culture using the medicinal mushroom Cordyceps militaris, Enzyme and Microbial Technology, 39(4), 641-646.

Nie, S., Cui, S. W., Xie, M., Phillips, A. O. \& Phillips, G. O. (2013). Bioactive polysaccharides from Cordyceps sinensis: Isolation, structure features and bioactivities. Bioactive Carbohydrates and Dietary Fibre, 1(1), 38-52.

Reis, F. S., Barros, L., Calhelha, R. C., Ćirić, A., Van Griensven, L. J. L. D., Soković, M. \& Ferreira, I. C. F. R. (2013). The methanolic extract of Cordyceps militaris (L.) Link fruiting body shows antioxidant, antibacterial, antifungal and antihuman tumor cell lines properties. Food and Chemical Toxicology, 62, 91-98.

Xu, Q., Liu, Z., Sun, Y., Ding, Z., Lü, L. \& Li, Y. (2012). Optimization for production of intracellular polysaccharide from Cordyceps ophioglossoides L2 in submerged culture and its antioxidant activities in vitro. Chinese Journal of Chemical Engineering, 20(2), 294301.

Yang, B. K., Ha, J. Y., Jeong, S. C., Das, S., Yun, J. W., Lee, Y. S., Choi, J. W. \& Song, C. H. (2000). Production of exo-polymers by submerged mycelial culture of Cordyceps militaris and its hypolipidemic effect. Journal of Microbiology and Biotechnology, 10, 784788.

Yoo, H. S., Shin, J. W., Cho, J. H., Son, C. G., Lee, Y. W., Park, S. Y. \& Cho, C.K. (2004). Effects of Cordyceps militaris extract on angiogenesis and tumor growth. Acta Pharmacologica Sinica, 25, 657-665.

Yu, H. M., Wang, B. S, Shiow, C. H. \& Duh, P.D. (2006). Comparison of protective effects between cultured Cordyceps militaris and natural Cordyceps sinensis against oxidative damage. Journal of Agricultural and Food Chemistry, 54(8), 3132-3138.

Yu, R., Yang, W., Song, L., Yan, C., Zhang, Z. \& Zhao, Y. (2007). Structural characterization and antioxidant activity of a polysaccharide from the fruiting bodies of cultured Cordyceps militaris. Carbohydrate Polymers, 70(4), 430436.

Wang, J., Kan, L., Nie, S., Chen, H., Cui, S. W., Phillips, A. O., Phillips, G. O., Li, Y. \& Xie, M. (2015). A comparison of chemical composition, bioactive components and antioxidant activity of natural and cultured Cordyceps sinensis. LWT-Food Science and Technology, 63(1), 2-7.

White, T. J., Bruns, T., Lee, S. \& Taylor, J. W. (1990). Amplification and direct sequencing of fungal ribosomal RNA genes for phylogenetics. In: Innis MA, Gelfand DH, Sninsky JJ, White TJ, editors. PCR Protocols: A Guide to Methods and Applications. New York, NY, USA: Academic Press, 315-322.

Won, S. Y. \& Park, E. H. (2005). Antiinflammatory and related pharmacological activities of cultured mycelia and fruiting bodies of Cordyceps militaris. Journal of Ethnopharmacology, 96(3), 555-561.

Wu, D. T., Xie, J., Wang, L. Y., Ju, Y. J., Lv, G. P., Leong, F., Zhao, J. \& Li, S. P. (2014). Characterization of bioactive polysaccharides from Cordyceps militaris produced in China using saccharide mapping. Journal of Functional Foods, 9(1), 315-323.

Zhan, Y., Dong, C. H. \& Yao, Y. J. (2006). Antioxidant activities of aqueous extract from cultivated fruit-bodies of Cordyceps militaris (L.) link in vitro. Journal of Integrative Plant Biology, 48(11), 1365-1370. 